Demokrasi dan Politik Pencitraan

\title{
DEMOKRASI DAN POLITIK PENCITRAAN PERANG IKLAN POLITIK MENUJU DEMOKRATISASI DI INDONESIA
}

\author{
Grendi Hendrastomo ${ }^{1}$
}

\begin{abstract}
Democracy has become one of the best governmental systems adopted by countries all over the world. Democracy has considered able to respond more intentions particularly public's in fighting for people's right. There must be at least under these three conditions for a country to be considered as democratic country. First, it must run general election, empowered civilians and freedom of the press. General election is one way a citizen can contribute in politic. General election is held every five years and is used as a media to distribute their voices by voting the representative who will become the spokeperson in the parliament.

To be a representative is not an easy job. Resources (social resources) are needed to win the popular vote. This is then why the representative democracy requires imaging. It is a common knowledge that the candidate of representative does not necessarily know the people he represent. Democracy raises the euphoria of creating image. In the end, war of image-making where character, quality, and individual's quality can be imaged and sell to public will happen.

Political commercial's war has spreaded which force people to enjoy. Democracy then is identical with politic of imaging. Voters then are similar as the decision makers of the economy. Political party or individual is voted based on its marketing, no different with the marketing of groceries. Economic capital has become political basis to someone hence finally creating the democratical chain which costs a big amount. Eventhoungh in one side, the politic of imaging lowers the quality of democracy; on the other hand, it gives political study to people so the public will gain more politic knowledge from the politic ads.
\end{abstract}

Key words: democracy, politic, imaging

\footnotetext{
${ }^{1}$ Pengajar di Program Studi Pendidikan Sosiologi, FISE, UNY
} 


\section{A. Pendahuluan}

Pemilihan umum (pemilu) menjadi salah satu syarat negara demokrasi. Ajang 5 tahunan ini menjadi peneguhan demokratisasi. Berbeda dari era orde baru dan orde lama, pemilu pada era reformasi penuh dengan gegap gempita euphoria rakyat untuk berpartisipasi dalam bidang politik. Partai-partai politik muncul seperti cendawan, partai-partai yang tidak lolos electoral threshold pemilu sebelumnya dan pecahan partaipartai besar bermetamorfosis menjadi partai-partai baru yang mengusung ideologi dan perubahan. Pemilihan umum yang ada di Indonesia baik untuk memilih wakil rakyat di DPR, presiden maupun pemilihan umum kepala daerah dijadikan sebagai ajang pendewasaan warga negara untuk melek politik. Kenyataannya keinginan untuk pendewasakan rakyat dijadikan alasan untuk menempatkan rakyat sebagai konsumen. Jualan partai selalu meninabobokkan rakyat dengan janji-janji kesejahteraan sekaligus utopia untuk menikmati kekuasaan. Berbagai macam cara untuk menjual partai dimata pemilih dilakukan dengan berbagai macam cara. Partai-partai baru dan kecil menjual partainya dengan sistem door to door dan lebih memanfaatkan jaringan kekeluargaan. Lain halnya dengan partai baru, besar dan memiliki banyak sumber dana, mereka dengan fleksibel bisa menggunakan berbagai macam alat pemasaran untuk menjual partai. Partai-partai besar yang mayoritas memiliki kursi di legislatif pun melancarkan berbagai upaya untuk berusaha menyakinkan konstituen partai dan warga negara untuk tetap memilih partainya pada pemilu mendatang.

Demokrasi yang idealnya merupakan sistem pemerintahan yang terbaik diantara sistem-sistem lain, memunculkan berbagai macam penafsiran di benak warga negara yang notabene awam akan dunia politik. Demokrasi bagi kebanyakan warga negara identik dengan pemilihan umum, bagi mereka pemilu inilah ajang demokrasi, ajang untuk memilih wakil-wakil mereka yang katanya akan memperjuangkan aspirasi rakyat di pemerintahan, memperjuangkan kesejahteraan mereka, memperjuangkan kehidupan yang lebih baik, aman, nyaman, tertib, dan damai.

Suatu negara dikatakan menganut sistem pemerintahan demokrasi ketika memenuhi paling tidak 3 prasyarat (Mallarangeng, 2008), pertama negara memiliki sistem aturan yang mengatur hak warga negara untuk menyampaikan pendapatnya, dan kebebasan berbicara, kedua kebebasan pers dan ketiga adanya pemilihan umum dengan motor penggerak demokrasi berada pada partai politik. Menurut Schumpeter (Huntington, 1997) prosedur utama demokrasi adalah pemilihan para pemimpin secara kompetitif oleh rakyat yang mereka pimpin. Dalam tataran sederhana ini bolehlah kita masukkan negara ini dalam negara demokrasi. Negara ini menjamin kebebasan berbicara dan berpendapat, pers kita bebas menyuarakan kebobrokan, kritis 
dan tajam, kita punya pemilu lima tahunan yang artinya kita memang menganut sistem pemerintahan demokratis. Tetapi kenyataannya demokratisasi di negara ini masing sering diperdebatkan karena perpektif dan cara memahami demokrasi yang berbeda-beda.

Bagi masyarakat, demokrasi mereka pahami dengan peningkatan kesejahteraan, sehingga ketika kesejahteraannya tidak kunjung membaik, mulailah mereka meragukan demokrasi. Pikiran-pikiran skeptis dan apatis tentang demokrasi kemudian mulai terbentuk. Keragu-raguan muncul dan romantisme otoritarian (orde lama dan orde baru) mulai berkembang. Masyarakat mulai membanding-bandingkan antara era orde baru dengan sekarang, munculah keinginan-keinginan untuk kembali ke masa itu yang bagi mereka merupakan masa yang bebas konflik, hidup aman, penuh dengan keteraturan, walaupun dibungkus dengan kediktatoran. Keragu-raguan akan demokrasi memunculkan ketidaktertarikan masyarakat terhadap proses demokrasi, pemilu salah satunya, maka mulai muncullah ancaman golput, konflik intra dan antar partai, hingga gerakan-gerakan yang ingin mengagalkan pemilihan umum. Kondisi ini diperparah dengan perilaku wakil-wakil rakyat yang berwatak penguasa, lupa pada konstituennya, dan baru ingat menjelang pemilihan umum tiba.

Pemilu dalam aras demokrasi merupakan prosedur kelembagaan untuk mencapai keputusan politik yang di dalamnya individu memperoleh kekuasaan untuk membuat keputusan melalui perjuangan kompetitif dalam rangka memperoleh suara rakyat (Huntington, 1997). Dengan kata lain, pemilu memang merupakan proses untuk menemukan wakil rakyat dengan kompetisi memperebutkan suara rakyat. Pada tataran ini, tidak heran kiranya, menjelang pemilu selalu ramai dengan hiruk pikuk calon wakil rakyat yang menggalang dukungan dengan mengunakan berbagai cara, melalui media, baik iklan, baliho, poster hingga mengadakan pertemuan setiap hari dengan harapan mendapatkan dukungan rakyat yang sebanyak-banyaknya. Pemilu menjadi ladang untuk membeli suara rakyat, politisi calon wakil rakyat kemudian berlombalomba untuk mem"populerkan" partai, nama dan nomor urut. Kampanye menjadi langkah awal politisi untuk berlari dan menjala suara yang mungkin bisa didapatkan dengan cara menyakinkan, memberi pengaruh hingga perang iklan politik. Bagi mereka, kampanye politik wajib dilakukan, karena inilah start awal perjuangan mereka meraih dukungan suara demi melanggengkan dan mendudukan mereka ditangga kekuasaan. Kemudian dalam perspektif ini, politik pencitraan menjadi sesuatu yang tidak bisa dipisahkan dari proses demokratisasi di Indonesia, terutama ketika dikaitkan dengan 
kampanye politik menjelang pemilihan, baik pemilihan calon legislatif, pemilihan kepala daerah, maupun pemilihan presiden.

Pencitraan identik dengan menonjolkan diri, membentuk persepsi masyarakat baik itu tentang partai maupun orang-orang berkepentingan di belakang partai. Pencitraan diperlukan sebagai sarana menjual "komoditas" partai dan cara efektif mengubah stigma negatif yang ada dalam masyarakat. Kampanye jelang pemilu kemudian menjadi ajang lomba untuk membentuk citra diri dan citra partai demi mengejar ambisi duduk di kursi panas wakil rakyat. Mengapa pencitraan penting? Pencitraan merupakan salah satu bentuk penanaman ideologi, perpektif ke dalam benak orang lain, dalam kontek politik pencitraan kemudian lebih melihat pada bagaimana menampilkan citra diri yang baik bagi masyarakat. Politik pencitraan kemudian banyak digunakan dalam berbagai kampanye politik. Kehadirannya boleh jadi bersamaan dengan kemunculan dunia politik itu sendiri. Bahkan, sejarah politik Roma mencatat tentang pengaruh pencitraan politik dengan modal rangkaian kata yang terus diucapkan saat kampanye mampu menggiring opini masyarakat dalam memilih. (http://www.pikiranrakyat.com/prprint.php?mib=berita detail\&id=37233). Representasi citra diri dalam iklan-iklan politik mencerminkan keinginan kandidat untuk menampakkan diri mereka sebagai representasi masyarakat umum yang memiliki sesuatu yang wajib dan harus diberi apresiasi untuk mewakili masyarakat.

Istilah representasi sosial mengacu pada produk dan proses yang menandai pemikiran pada masyarakat awam (diambil dari kata common sense dan untuk selanjutnya akan disebut sebagai pikiran awam), suatu bentuk pemikiran praktis, secara sosial dielaborasi, ditandai oleh suatu gaya dan logika khas, dan dianut oleh para anggota sebuah kelompok sosial atau budaya (Jodelet, 2006). Iklan politik yang merupakan bagian dari representasi sosial, diproduksi untuk menciptakan image yang mendorong orang memunculkan ketertarikan. Pencitraan kemudian dimaknai sebagai alat untuk mengapai kekuasaan.

Pencitraan yang ditampilkan melalui iklan politik menabiskan bahwa selama ini ada kecenderungan calon legislative elit partai tidak dekat dengan konstituennya. Elit politik malah sibuk dengan kepentingan pribadi dan kepentingan partainya masingmasing. Pada kenyataannya, Parpol masih melihat rakyat sebagai "supporter" bukan sebagai "voters" yang sesungguhnya. Celakanya lagi, orientasi partai untuk merebut voters tidak dengan memperjuangkan kepentingankepentingan vital mereka, tetapi lebih dengan memanipulasi sentimen-sentimen primordial seperti etnisitas dan agama, penggunaan politik uang, hingga memanage psikologi masyarakat dengan penampakan citra diri (Nababan, 
http://www.demosindonesia.org/ pdf/Reformasi $\% 20$ Kepartaian $\% 20$ u ntuk\%20Perbaikan\%20Representasi. pdf).

Sebagian besar masyarakat masih memandang partai politik belum sepenuhnya mampu mengemban aspirasi rakyat atau berpihak kepada kepentingan rakyat yang diwakilinya (Kompas, 12 Januari 2009). Untuk itulah pencitraan menjadi salah satu modal kampanye yang harus dilakukan.

Jajak pendapat kompas (Januari 2009) beberapa waktu yang lalu citra partai politik masih dianggap buruk, hanya 39,6\% responden yang menganggap citra partai sudah baik. Hal inilah yang menjadi salah satu alasan partai berlomba-lomba untuk mengkampanyekan partainya dengan berbagai media komunikasi, baik iklan dimedia, poster baliho maupun pamlet dan poster. Munculnya mahkamah konstitusi atas uji materi UU No 10 tahun 2008 tetang pemilihan umum, semakin memunculkan pertarungan pencitraan diantara calon anggota legislatif. Mahkamah konstitusilah yang mengubah calon legislatif terpilih tidak lagi berdasarkan nomor urut tetapi dengan suara terbanyak semakin membuat hingar bingar panggung politik di negara ini. Disatu sisi, keputusan MK ini mentahbiskan demokratisasi di negara ini, siapa yang terpilih memang benar-benar pilihan mayoritas rakyat, tetapi disisi lain keputusan MK ini bisa menjadi blunder demokrasi dimana peran parpol dikerdilkan oleh peran individu, membengkakkan biaya kampanye, hingga konflik yang mungkin terjadi diantara partai. Politik pencitraan kemudian menjadi sangat penting bagi calon legislatif dan kampanye politik akan semakin mewarnai dinamika masyarakat kita. Artikel ini kemudian akan banyak membahas tentang politik pencitraan dalam demokrasi, apa dan bagaimana politik pencitraan membawa perubahan atau justru kemunduran dalam proses demokratisasi, dan peran kampanye politik menjelang pemilu tahun ini.

\section{B. Politik Pencitraan Sisi Lain Demokrasi}

Dalam politik (pemilu), pencitraan selalu identik dengan "show off" pamer, menonjolkan diri maupun partai dengan mengedepankan ideologi, visi, berbagai macam perubahan hingga simbol-simbol tertentu yang akan memudahkan massa pemilih dalam mengingat partai maupun calon legislatifnya. Politik pencitraan intinya ingin membuat orang lain (pemilih) terpesona, kagum, memunculkan rasa ingin tahu, memunculkan kedekatan yang memang sengaja dibangun demi popularitas. Selama ini apabila berbicara tentang pencitraan mau tidak mau selalu kita identikan dengan media, iklan televisi, radio. Pencitraan juga identik dengan selebriti, pejabat yang menginginkan penampilan terbaik 
(positif) yang akan selalu diingat dan mengubah citra negatifnya.

Dalam demokrasi, pencitraan menjadi penting karena adanya representasi suara yang disematkan ketika seseorang berlomba-lomba menjadi "wakil rakyat". Seseorang yang ingin menjadi wakil rakyat paling tidak harus dikenal oleh massa pemilih dan kepentingan untuk menampilkan sosok dirinya dengan harapan massa pemilih akan memilih dirinya. Konteks wakil rakyat sendiri bisa diperdebatkan. Idealnya, semua orang memiliki kans yang sama untuk menjadi wakil rakyat. Masyarakat sebagai warga negara biasa mempunyai akses sama ke politik. Dalam kenyataanya, akses ini dibagi secara tidak merata. Pembagian itu ditentukan berdasarkan tingkat pendidikan, kepemilikan pada kelompok/agama dan posisi geografis. Ketiga faktor itu mencerminkan besarnya kapital yang dimiliki (kapital budaya, sosial, ekonomi, dan simbolik). Kepemilikan kapital menentukan hubungan kekuasaan yaitu daya tahan terhadap hak-hak mereka (Haryatmoko, 2008)

Model pendelegasian ini menjadi salah satu sebab lemahnya pengawasan terhadap pelaksanaan kekuasaan. Maraknya korupsi, tidak peduli terhadap kepentingan rakyat, diabaikannya kesejahteraan bersama dan hanya peduli pada politik pencitraan. Kepedulian akan muncul ketika pencitraan diperlukan, ketika kepentingan untuk melanggengkan atau mencapai kekuasaan memerlukan retorika demi mencapai hasil yang diinginkan.

Bagi calon wakil rakyat, pencitraan akan membantu mereka menampakkan sisi baik dan mempopulerkan diri mereka pada calon pemilih. Bagi politisi yang sekarang menikmati empuknya kekuasaan, pencitraan penting untuk menyebarkan capaian hasil dan perubahan, janji-janji yang akan dilakukan, mengubah citra negatif menjadi positif demi untuk melanggengkan kekuasaannya, karena obsesi politisi adalah kekuasaan (dipilih kembali) bukan dalam rangka mengupayakan kesejahteraan bangsa melainkan sebagai akses ke fasilitas dan kenikmatan social. Disinilah calon politisi baru berusaha untuk mencitrakan diri mereka, demi meraih suara konstituen dengan mengobral janji-janji, berjualan perubahan, menyakinkan massa akan memperjuangkan aspirasi mereka hingga pemberian dana pembangunan apabila kelak benarbenar terpilih.

Pemilu menjadi proyek besar untuk mulai perjuangan saling mengalahkan demi kursi kepresidenan, legislative maupun kepala daerah. Politisi berlombalomba membentuk citra diri yang baik dengan menggunakan berbagai macam cara. Iklan di berbagai media baik televisi, radio maupun media cetak menjadi salah satu cara yang dirasa paling efektif untuk mensosialisasikan dan memperkenalkan diri mereka ke massa pemilih. Di sepanjang pinggiran jalan, di dalam bus kota, papan pengumuman, iklan politik 
telah memenuhi ruang publik kita. Politik tidak lagi hanya berdagang ide melalui diskusi, seminar, kuliah, wawancara dan debat kusir. Bahkan, politik mulai masuk ke teknik merayu, memamerkan gagasan politik, meniru iklan-iklan konsumtif yang selalu menawarkan produk yang terbaik dengan bumbu-bumbu yang unik yang membedakan dengan produk lain.

Sifat dari iklan politik sebagai media yang mampu merengkuh simpati calon pemilih, menyebabkan media ini paling cocok untuk menjual citra diri. Ada dua alasan mengenai pentingnya pencitraan. Pertama, secara ekonomi bisa dilihat bahwa warga negara/masyarakat/konstituen

bukan hanya sekedar konsumen yang tidak puas, warga negara dihadapkan pada tekanan untuk membeli atau memilih. Keputusan memilih produk kemudian tergantung dari pencitraan dan pemasarannya. Disitulah kampanye, iklan politik diharapkan mampu memikat pemilih. Kampanye/iklan politik layaknya iklan produk yang mempermainkan imajinasi dan menumbuhkan rasa tertarik pada individu untuk mencoba, merasakan dan akhirnya memilih produk yang ditawarkan. Walaupun mungkin dari bobot isi dan substansi politik banyak dikesampingkan tetapi yang penting mampu merangsang imajinasi perubahan, sehingga tidak heran apabila yang dikedepankan adalah foto diri, nama, nomor urut, cara memilih dan sedikit retorika politik (eg, kreatif, produktif konstruktif, jujur dan peduli). Pencitraan bukan lagi sekedar memoles sisi negatif politisi yang secara manusiawi memiliki kekurangan, melainkan sudah menjadi lampu aladin yang diharapkan dapat mengubah hitam menjadi putih (Kristiadi, 2008).

Kedua, secara politik, titik tolaknya adalah tantangan bahwa pada dasarnya demokrasi memperkenalkan suatu derajat ketidakpastian dalam proses politik. Dalam sebuah demokrasi, tidak ada satu kelompokpun yang yakin bahwa kepentingannya akan menang, bahkan kelompok yang paling kuat, semua harus siap menghadapi kemungkinan bahwa mereka bisa saja kalah dalam pertarungan dengan kelompok lain yang berarti keinginannya tidak terpenuhi (Sorensen, 2003). Dengan kata lain, karena ketidakapastian menang atau kalah itulah yang menyebabkan calon legislatif berusaha memenangkan pencitraan nya demi mendekatkan pada kemenangan. Hal inilah yang kemudian dikemukakan oleh Boni Hagens (Kompas, 7 Januari 2009) sebagai salah satu tirani demokrasi yaitu tirani popularitas yang mengacu pada penekanan berlebihan pada aspek citra sehingga kinerja dinomor sekiankan. Popularitas diutamakan sedemikian rupa sehingga implementasi politik hanyalah sebuah aksi tebar pesona. Politik yang sesungguhnya menyangkut siapa yang paling banyak menyebar 
stiker, membagi kaos dan membagikan pin. Politik adalah urusan siapa yang paling popular.

Kekhawatiran bahwa wakil rakyat yang terpilih bukan benarbenar mampu dan bermutu mengemuka ketika popularitas dan pencitraan justru membuat pemilih salah pilihan, mereka yang popular justru dengan mudah melenggang masuk ke lembaga legislatif daripada mereka yang benar-benar mampu dan bermutu. Bahkan saat inipun komposisi anggota DPR RI menurut Idrus Marham (Kompas, 18 Januari 2009) hanya 40 \% yang konseptual dan bermutu, sedangkan sisanya ditengarai tidak bermutu dan hanya mengejar kekuasaan.

Pencitraan dalam demokrasi menjadi sesuatu hal yang wajar dan logis, dimana semua memiliki kemungkinan yang sama untuk dipilih. Citra seseorang akan menambah maraknya demokrasi dan membantu tercapainya demokrasi masyarakat sipil ketika janji-janji yang dicitrakan dan ditampilkan benar-benar mampu membawa perubahan dan kesejahteraan masyarakat.

\section{Iklan Politik Mencederai Demokrasi?}

Iklan politik mulai merebak pada pemilihan umum 1999 ketika Indonesia kembali mengadopsi sistem multipartai. Partai-partai baru, termasuk partai lama perlu mengiklankan agar dikenal para pemilih. Dalam pemilu 2009, iklan politik bukan lagi barang baru, bahkan sudah menjadi prasyarat umum bagi partai politik supaya dikenal oleh masyarakat maka harus beriklan. Iklan politik merupakan bagian dari kampanye politik yang selalu mendapatkan porsi berlebih karena efektifitasnya dalam memperkenalkan nama, ideologi, dan visi parpol.

Kampanye politik menjadi instrumen yang memegang peran penting dalam memandu kesadaran publik pada sosok dan citra diri calon. Kampanye menjadi ajang bagi para kandidat presiden, anggota legislatif maupun partai politik untuk secara bebas memasuki relung kesadaran publik melalui pemasaran politik yang terkonsep. Namun, kampanye juga bisa menjadi alat ampuh manipulasi kesadaran politik dan mensubordinasikan publik dalam situasi tuna kuasa tanpa pemahaman politik yang memadai.

Iklan politik sebagai salah satu kampanye politik mulai berkembang ketika kontestan pemilu mulai menyadari bahwa metode kampanye konvensional dengan mengelar rapat akbar, arakarakan tidak lagi memadai untuk menggaet suara pemilih. Iklan politik dianggap mampu mengisi kekosongan kampanye konvensional. Merebaknya iklan politik menyebabkan partai-partai politik mulai menggunakan jasa professional perusahaan periklanan untuk membuat iklan yang dapat membujuk pemilih. Survei-survei yang dilakukan lembaga independen yang dipublikasikan hampir setiap bulan yang menampilkan kondisi teraktual simulasi pemilih turut mempengaruhi jumlah iklan politik. Partai-partai yang dalam survei 
tersebut berada di posisi bawah berusaha menambah iklan politik dengan harapan akan menaikkan hasil survei berikutnya. Bahkan ditengarai ada beberapa parpol yang justru melakukan survei dengan hasil yang menguntungkan parpolnya demi meraih simpati dan dukungan dari massa pemilih.

Data AC Nielsen mencatat bahwa biaya iklan pemerintahan dan politik pada tahun 2008 telah mencapai 2,2 triliun atau naik sebesar 66\% dibandingkan dengan tahun 2007 yang hanya 1,3 triliun (Kompas, Januari 2009) atau jauh dari iklan politik pemilu 1999 yang hanya 35,6 miliar (Setiyono, 2008). Angka ini diprediksi akan melonjak mendekati pemilu 2009. Biaya iklan politik yang membengkak terjadi karena iklan politik merupakan alat yang efektif mendokrak popularitas parpol, yang telah dibuktikan pada pemilu 2004. Efektivitas iklan politik terjadi karena belum selesainya hysteria media, khususnya televisi. Televisi hampir selalu ditemukan baik itu dipemukiman kumuh atau pelosok Indonesia. Hampir semua yang disiarkan media dilahap masyarakat (Kompas, 12 Januari 2009).

Sebegitu mahalkan demokrasi? Demokrasi memang mahal namun tidak seperti oligarki, aristorkrasi atau kediktatoran, demokrasi menyediakan ruang bebas bagi para politikus untuk bersaing secara kreatif. Maraknya iklan di media massa barangkali diakibatkan oleh rendahnya keterikatan antara parpol dan masyarakat. Menurut Robert Dahl, suatu negara dapat dikatakan demokratis apabila ada sinergi antara parlemen (elit politik) dengan civil society, yang terjadi di Indonesia parlemen sudah semakin membaik tetapi civil society tidak digarap secara maksimal, dan baru digarap menjelang pemilihan umum. Inilah yang menumbuhkan iklan politik sebagai cara untuk memperkenalkan partai pada masyarakat. Iklan menjadi sarana menutup kelemahan parpol selama ini, khususnya dalam menumbuhkan keterkaitan dengan masyarakat. Itupun dengan syarat iklan yang dibuat benar-benar mampu menjadi pendidikan politik bagi masyarakat, iklan politik yang tidak mendidik dan jauh dari pesan pendidikan politik justru telah mencederai demokrasi. Jangan sampai kemudian justru terjadi perubahan dari demokrasi menjadi mediakrasi. Iklan tidak diperlukan ketika partai politik benar-benar membangun jaringan di masyarakat, berusaha untuk memberikan pendidikan politik dan benar-benar menyuarakan aspirasi masyarakat.

Kekhawatiran lain menyangkut iklan politik adalah bahwasannya iklan politik yang muncul di tengah kesadaran dan pengetahuan sebagian besar masyarakat yang rendah terhadap politik mengakibatkan iklan cenderung langsung diterima tanpa pengkritisan sebelumnya. Kondisi seperti ini akhirnya hanya menampilkan politik ikon/simbol 
yaitu politik yang berdasarkan ikon yang dibentuk dengan citra tertentu di media massa. Resiko salah pilih kemudian menjadi sebuah pertaruhan yang mahal (Kompas, 21 Januari 2009).

Booming iklan politik diperkirakan justru akan meningkat menjelang detik-detik terakhir pemilihan, hal ini semakin diperjelas dengan keputusan MK tentang keterwakilan berdasarkan suara terbanyak. Keputusan MK tersebut akan memperbanyak iklan politik karena calon legislatif yang tadinya berada di nomor urut bawah mulai menemukan momentumnya untuk mewujudkan mimpi duduk di kursi wakil rakyat. Situasi ini kemudian memunculkan dilema, pertama, putusan MK ini akan disikapi dengan membanjirnya permintaan iklan politik, baik dalam bentuk poster, stiker, pamlet, kaos dan alat peraga lainnya, akan memunculkan perang iklan politik yang apabila tidak diperhatikan dan diatur justru akan menyebabkan masyarakat bosan dan justru enggan memilih, kedua, berbagai macam obral janji dan retorika yang divisualisasikan lewat iklan justru berlawanan dengan representasi riil tentang wakil rakyat. Wakil rakyat yang banyak diberitakan korupsi di satu sisi dan perang iklan di sisi lain justru akan memunculkan perlawanan dan ketidakpercayaan masyarakat pada demokrasi yang justru akan melemahkan momentum demokratisasi dan memperkuat pihak-pihak yang menginginkan pemerintahan otoritarianisme.
Ketiga,

pemilihan

berdasarkan suara terbanyak akan membuat ekonomi kecil tumbuh, hal ini sementara terbukti dengan mengeliatnya usaha sablon, pemasangan iklan dan usaha konveksi yang mengalami peningkatan lebih dari 2 kali lipat (Kompas, 21 Januari 2009) dari order yang diberikan calon legislatif yang semakin bertambah. Keempat, biaya kampanye politik secara keseluruhan akan membengkak yang akan memunculkan pendapat miring tentang pesta demokrasi yang hanya mengamburhamburkan dana, padahal justru tidak ada peningkatan kesejahteraan yang dirasakan rakyat kecil. Kelima, kemungkinan besar wakil rakyat yang terpilih berdasarkan kekayaan yang dimiliki, semakin banyak modal yang dikeluarkan maka peluang terpilihnya semakin besar, sehingga muncul kekhawatiran wakil rakyat yang berkuasa justru mereka-mereka yang terpilih karena kekayaannya bukan karena kapasitasnya atau justru mereka yang terpilih akan berusaha segera mengembalikan modal awal dengan menghalalkan segala cara.

Keputusan MK disatu sisi sangat disikapii positif sebagai output demokrasi dimana suara rakyat memiliki nilai, tetapi disatu sisi ini juga bisa menjadi boomerang bagi partai dimana citra individulah yang akan ditonjolkan dibandingkan citra partai. Pada akhirnya nantinya partai justru tersandera untuk mencari ikon atau tokoh yang terkenal untuk merauk suara. Kondisi yang demikian justru akan membahayakan demokrasi 
dikarenakan popularitas menjadi prasyarat mutlak untuk menjadi wakil rakyat. Padahal dalam demokrasi popularitas saja tidak cukup, justru yang sangat diperlukan adalah individu yang kompeten dalam dunia perpolitikan terutama karena wakil rakyat cenderung akan menjadi ujung tombak pembuatan undang-undang yang menjadi pengejawantahan hak-hak rakyat.

Iklan politik menjadi media untuk jualan calon wakil rakyat dan partainya sekaligus juga ada harapan dengan iklan politik rakyat menjadi melek politik sehingga partisipasi politiknya menjadi lebih baik. Perlu digarisbawahi bahwa keberadaan iklan politik menjadi ajang untuk mengaktualisasikan kerangka pikir yang akan diberikan, walaupun tentu saja keberadaan iklan politik perlu diatur terutama karena ongkos pencitraan yang mahal. Pencitraan yang mahal akan membuat biaya politik menjadi tinggi, ujung-ujungnya politisi yang duduk di kekuasaan akan tersandera dengan pembiayaan, yang berakibat munculnya korupsi dan kongkalikong proyek-proyek pemerintah.

Mau tidak mau, suka tidak suka, iklan politik telah memasuki ruang publik kita, sisi positifnya inilah salah satu bentuk demokrasi kita dimana masing-masing pihak/parpol secara terbuka berkompetisi secara kreatif untuk mendulang sebanyak-banyaknya suara. Walaupun kemungkinan yang terjadi bisa sebaliknya, justru akan mencederai demokrasi. Tetapi inilah tantangan yang harus dihadapi ketika kita menginginkan demokrasi yang sebenarnya.

\section{Kesimpulan}

Politik pencitraan yang terbungkus dalam iklan politik telah menjadi bumbu yang diharapkan dapat memperkuat rasa demokrasi di negara ini. Politik pencitraan telah menjadi sesuatu hal yang penting dalam demokrasi abad informasi, karena melaluinya aneka kepentingan, ideologi, dan pesan politik dapat dikomunikasikan. Iklan politik yang semakin massif terutama setelah mendapatkan momentum dari keputusan MK tentang perwakilan berdasarkan suara terbanyak, perlu disikapi secara kritis.

Pertama, kemungkinan keputusan ini akan mengkerdilkan peran parpol yang selama ini identik dengan motor pengerak demokrasi. Pendulum demokrasi sekarang mulai bergerak ke individu dan memunculkan dugaan bahwa partai hanya dipergunakan sebagai alat untuk memenuhi kepentingan individu, peran parpol akan dilemahkan oleh peran individu karena mereka mengklaim suara yang dihasilkan adalah suara yang mereka usahakan bukan usaha parpol. Kedua, kemungkinan muncul konflik internal parpol semakin besar, lawan politik tidak hanya beda parpol, justru konflik akan dipicu perebutan konstituen partai demi memperebutkan suara 
terbanyak. Situasi ini akan serba menyulitkan parpol karena calon anggota legislatifnya justru bertarung secara tidak sehat, yang akhirnya justru akan melemahkan parpol. Ketiga, perang modal menjadi hal yang jamak dilakukan, kebanyakan digunakan untuk mendongkrak citra yang juga memunculkan kekhawatiran munculnya money politics. Ketergantungan pada modal juga memunculkan kekhawatiran politisi didanai oleh perusahaan, komprador yang meminta "balas jasa" ketika berhasil memenangkan pemilu. Keempat, kemungkinan keterwakilan perempuan menjadi semakin kecil. Budaya patrilineal yang mengakar kuat dalam budaya kita akan menyulitkan perempuan untuk terpilih berdasarkan suara terbanyak.

Sisi positifnya adalah, adanya harapan bahwa dari perwakilan berdasarkan suara terbanyak, merupakan wakil yang sesungguhnya dari rakyat yang mengemban amanat rakyat dan diharapkan benar-benar mampu menyuarakan aspirasi mereka. Kedepannya, calon legislatif juga akan berusaha mendekatkan diri, mengarap konstituennya dari awal, tidak perlu menunggu hingga detikdetik akhir jelang pemilu, karena inilah modal awal mereka untuk kampanye pemilu lima tahun mendatang. Disamping itu, perlu pula menekankan pada landasan etika politik, karena tugas politik tidak hanya menghimpun konstituen sebanyak mungkin, tetapi yang lebih penting adalah membangun masyarakat politik yang sehat, cerdas dan berkelanjutan.

\section{Daftar Pustaka}

Haryatmoko, 2008., Demokrasi

Dikoreksi [online] tersedia pada

URL:

<http://www.kompas.com/kompa

scetak.php/read/xml/2008/04/23/

00263239/demokrasi.dikoreksi>

[diakses pada 28 Januari 2009]

Huntington, Samuel, 1995.,

Gelombang Demokratisasi Ketiga,

Jakarta: Grafiti

Kristiadi, 2008., Kampanye dan

Demokrasi Prosedural [online]

tersedia pada URL:

<http://cetak.kompas.com/read/x $\mathrm{ml} / 2008 / 07 / 22 / 00232282 /$ kampan ye.dan.demokrasi> [diakses pada 28 Januari 2009]

Mallarangeng, Rizal, 2008. Dari

Langit, Kumpulan Esai tentang

Manusia, Masyarakat dan Kekuasaan, Jakarta: Kepustakaan Populer Gramedia

Muchtar, Tenriangke, 2008., Iklan

Politik: Simbol Ketidakpekaan Elite

[online] tersedia pada URL:

$<$ http://theindonesianinstitute.com

Lindex.php/20080923269/Iklan-

Politik-Simbol-Ketidakpekaan-

Elite.html> [diakses pada 11 Januari 2009]

Nababan, Asmara, Reformasi

Kepartaian untuk Perbaikan

Representasi [online] tersedia pada

URL:

< http://www.demosindonesia.org 
| Demokrasi dan Politik Pencitraan

/pdf/Reformasi \%20Kepartaian \%20 untuk\%20Perbaikan\%20Representas i.pdf> [diakses pada 7 Maret 2009]

Prasetya, Dani, 2009. Baliho Kandidat Legislator Marak di Mana-mana Pencitraan atau "Penampakan"? [online] tersedia pada URL: $<$ http://www.pikiranrakyat.com/prprint.php?mib=berita $\underline{\text { detail\&id }=37233}>$ [diakses pada 9 Maret 2009]

Robet, Robertus, Merehabilitasi Konsep Politik [online] tersedia pada URL:

<http://www.tifafoundation.org/fi les/PAPER\%20ROBET(1).pdf> [diakses pada 25 Januari 2009]

Setiyono, Budi, 2008., Iklan dan Politik, Menjaring Suara Dalam Pemilihan Umum, Yogyakarta:Galang Press

Sorensen, Georg, 2003., Demokrasi dan Demokratisasi, Yogyakarta: Pustaka Pelajar

Artikel Koran

Alfian, Alfan, Demokrasi Pilihlah Aku, Kompas, 12 Januari 2009 hal 6 Amir Piliang, Narsisisme Politik, Kompas, 17 Januari 2009 hal 6 Buah Manis Kampanye Pemilu 2009, Kompas 21 Januari 2009 hal Yogyakarta Demokrasi Terancam, Kompas 18 Januari 2009 hal 2 Hargens, Boni, Tirani Ganda Demokrasi, Kompas 7 Januari 2009 hal 6 Iklan Politik dan Politik Ikon, Kompas 21 Januari 2009 hal 5
Kemakmuran Rakyat, Popularitas dan Realisasi Janji, Kompas 7 Januari 2009 hal 4 Sesama Caleg Satu Partai Saling Melaporkan, Kompas, 30 Januari 2009 hal 4 Survei Jadi Bisnis Besar, Kompas 16 Januari 2009 hal 3 
| Grendi Hendrastomo

DIMENSIA, Volume 3, No. 2, September 2009 | 14 